\title{
Pengenalan Gerak Manusia Menggunakan Algoritma Relevance Vector Machine pada MSRC-12 Dataset
}

\author{
Vina Ayumi1, Erwin Dwika Putra2 \\ 1 Fakultas Ilmu Komputer, Universitas Mercu Buana \\ Jl. Raya Meruya Selatan, Kembangan, Jakarta, Indonesia, 11650 \\ E-mail: vina.ayumi@mercubuana.ac.id \\ 2 Fakultas Teknik, Universitas Muhammdiyah Bengkulu \\ Jl. Bali, Kota Bengkulu, Indonesia, 38119
}

\begin{abstract}
Relevance vector machine is a popular machine learning technique that is motivated by statistical learning theory. RVM can be used for gesture recognition which is one of the communication tools used by humans. This study proposes an experiment using the Relevance Vector Machine (RVM) algorithm on gesture data from Microsoft Research Cambridge-12 (MSRC-12) as a proposed solution to overcome unbalanced problems in data processing. The results of the study are the accuracy for 1-person motion model reaches $100 \%$ and the lowest accuracy with 5 people the motion model reaches $96 \%$. Graphically, the more people or models, the lower the algorithm's accuracy.
\end{abstract}

Abstrak - Relevance vector machine merupakan salah satu teknik pembelajaran mesin yang populer yang dimotivasi oleh statistical learning theory. RVM dapat digunakan untuk pengenalan gerak atau gesture yang merupakan salah satu alat komunikasi yang digunakan manusia. Penelitian ini mengusulkan eksperimen menggunakan algoritma Relevance Vector Machine (RVM) pada data gesture dari Microsoft Research Cambridge-12 (MSRC-12) sebagai usulan solusi dalam mengatasi masalah unbalanced pada proses pengolahan data. Hasil dari penelitian adalah akurasi untuk 1 orang model gerak mencapai $100 \%$ dan akurasi terendah dengan 5 orang model gerak yang mencapai $96 \%$. Secara grafik semakin banyak jumlah orang atau model, maka semakin menurun tingkat akurasi algoritma.

Keywords - MSRC-12, relevance vector machine, machine learning

\section{Pendahuluan}

Algoritma relevance vector machine (RVM) merupakan salah satu teknik pembelajaran mesin yang populer yang dimotivasi oleh statistical learning theory [1]. RVM menjadi populer karena memiliki fitur yang menarik secara teoritis dan kinerja empiris yang mendalam [2][3]. Namun RVM memiliki kekurangan, seperti halnya statistical learning theory selama masa pelatihan, seluruh data training diasumsikan seimbang tiap kelasnya, padahal pada penerapan di dunia nyata kita sering menemukan adanya jumlah data training yang tidak seimbang pada tiap kelasnya [4].

Beberapa penelitian telah mengusulkan statistical learning theory yang menangani unbalanced pada data [4]-[11]. Li et al. [4] mengusulkan fuzzy relevance vector machine untuk mengatasi unbalanced dan noise pada data dengan memberikan pembobotan pada punishment terms of error dalam proses Bayesian inference di RVM. Sementara itu Song et al. [7], mengusulkan distribution-sensitive prior untuk mengatasi masalah unbalanced pada data dengan menganalisi data training sebelum mempelajari model, dan memberikan bobot yang lebih pada sampel kelas yang kurang terwakili (kelas dengan jumlah data yang lebih sedikit) [7].
Penelitian ini mengusulkan eksperimen menggunakan algoritma RVM pada data gesture dari Microsoft Research Cambridge-12 (MSRC-12) sebagai usulan solusi dalam mengatasi masalah unbalanced pada proses pengolahan data sehingga dapat meningkatkan hasil akurasi pengenalan gerak manusia.

\section{Studi Literatur}

\section{A. Relevance Vector Machine (RVM)}

Algoritma relevance vector machine (RVM) merupakan teknik regresi dan klasifikasi dalam bentuk model Bayesian dari Generalized Linear Model (GLM) yang memiliki fungsi identik dengan SVM [3].

Meskipun SVM memiliki kinerja yang sangat baik, namun memiliki kelemahan yang signifikan, antara lain [12]-[14]:

1. Meskipun SVM relatif sparse, jumlah support vector biasanya bertambah secara linier seiring dengan bertambahnya jumlah traning set.

2. Prediksi tidak bersifat probabilistic, oleh karenanya SVM tidak cocok untuk klasifikasi dimana posterior probability of class membership diperlukan. 
3. SVM membutuhkan estimasi error/margin berupa parameter regularisasi atau constraint, dimana umumnya menggunakan cross validation yang boros pada data dan komputasi.

4. Fungsi kernel SVM $K\left(x, x_{i}\right)$ harus memenuhi kondisi Mercer.

RVM merupakan Bayesian treatment yang tidak memiliki keterbatasan seperti SVM. RVM memiliki keunggulan terhadap SVM yaitu RVM dapat menghasilkan decision function (relevance cector) yang lebih sedikit daripada SVM [4]-[11].

RVM merupakan model non-linear probabilistic dengan prior distribution pada bobot yang membuat solusi menjadi lebih sparse, RVM tidak membutuhkan tuning parameter regularisasi (parameter constraint) apapun selama pelatihan, dan RVM tidak mengharuskan fungsi kernel $K\left(x, x_{i}\right)$ memenuhi kondisi Marcer seperti SVM. Fungsi kernel memenuhi kondisi Mercer apabila fungsi kernel tersebut bersifat simetris dan positive definite [4]-[11].

RVM merupakan model non-linier probabilistik dengan prior distribution pada bobot yang mempertahankan sparsity. Prosedur prediksi bobot dilakukan dalam fully probabilistic framework. Pada masalah regresi, RVM melakukan prediksi berdasarkan fungsi [4]-[11]:

$$
y(x, w)=\Sigma^{N} w_{i=1} K\left(x, x_{i}\right)+w_{0}
$$

dimana $K\left(x, x_{i}\right)$ adalah fungsi kernel, yang mendefinisikan sebuah basis function untuk setiap sampel dalam training set, dan $w=\left(w 0, w 1, \ldots, w_{N}\right)$ $T$ adalah parameter yang dicari (unknown parameter). Untuk itu kita memperlakukan parameter-parameter tersebut sebagai random variabel yang diambil dari distribusi tertentu. Misalkan dapat kita berasumsi bahwa parameterparameter tersebut terdistribusi secara gaussian dengan mean zero dan variance $\sigma_{2}$ [4]-[11].

\section{B. Human Gesture Recognition}

Human gesture recognition sendiri bertujuan melakukan analisis secara otomatis berbagai macam gesture dalam aktivitas manusia [15]. Metode pengenalan gesture telah dikembangkan menggunakan data video, motion capture, depth data atau beberapa kombinasi dari modalitas tersebut [15].

Terdapat dua tahapan dalam prosedur human gesture recognition yaitu a. human detection dan action feature extraction; dan b. gesture classification. Performansi final recognition dipengaruhi oleh pemilihan metodologi yang digunakan pada kedua tahap ini [5].

\section{Metode Penelitian}

Secara umum rencana eksperimen yang akan dilakukan dapat dideskripsikan pada gambar berikut.

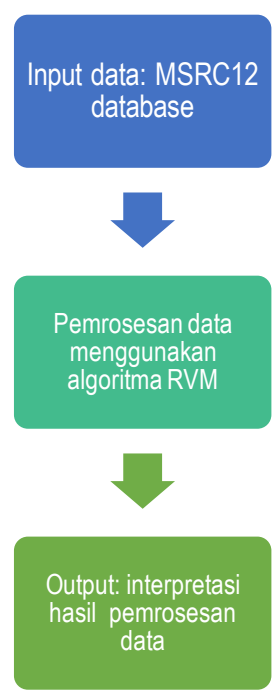

Gbr. 1 Tahapan Penelitian

Data yang digunakan pada penelitian ini merupakan data yang diperoleh dari MSRC12 database yang terdiri dari 12 gesture. Input berupa urutan frame skeleton joint yang di susun dalam bentuk matriks, dengan kolom merepresentasikan motion feature $M^{t}=\left\{m^{t}, m^{t}, \ldots, m^{t}\right\}$ dengan dimensi $20 \times 3=60$, dan baris merepresentasikan frame.

Data pelatihan akan dilakukan pembelajaran dengan RVM yang bertujuan untuk mengestimasi model parameter yang dipelajari dari data pelatihan dan label. Model kemudian akan digunakan untuk memprediksi target label pada data yang belum diketahui.

Hasil pembelajaran menggunakan RVM akan diinterpretasi untuk mengetahui bagaimana hasil akurasi pengenalan gerak manusia.

\section{Hasil Penelitian}

Eksperimen dilakukan untuk mengetahui performansi algoritma RVM pada dataset MRSC12. Eksperimen dilakukan dengan cross-validasi, dimana 2/3 dari data diperlakukan sebagai data training, dan sisanya sebagai data testing. Agar perbandingan yang dilakukan setara, kernel yang digunakan masing-masing ekperimen sama yaitu Radial Basis Function (RBF), dengan skala 0.3. Eksperimen dilakukan menggunakan data MRSC12 terdiri dari 12 gesture.

Gambar 2 berikut ini menujukkan akurasi pengenalan menggunakan algoritma RVM yang dilakukan sebanyak 5 kali yang terdiri dari 1 sampai 6 orang. 


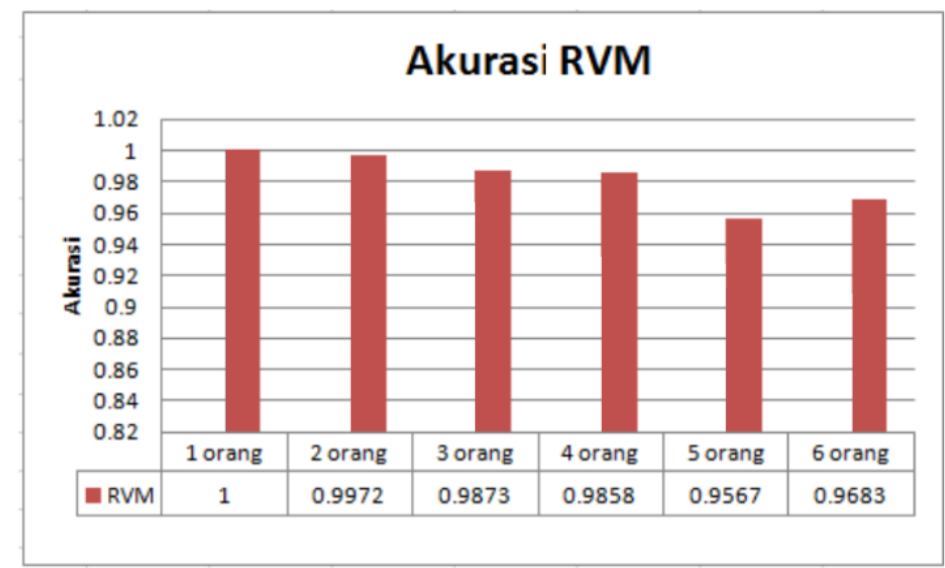

Gbr. 2 Akurasi Algoritma RVM

Dari hasil eksperimen, RVM menghasilkan decision function dalam hal ini relevance vector yang meningkat linier dengan jumlah orang pada dataset yang diteliti.
Gambar 3 dibawah ini memperlihatkan jumlah relevance vector yang dihasilkan oleh RVM dari hasil eksperimen yang telah dilakukan terhadap dataset Microsoft Research Cambridge-12.

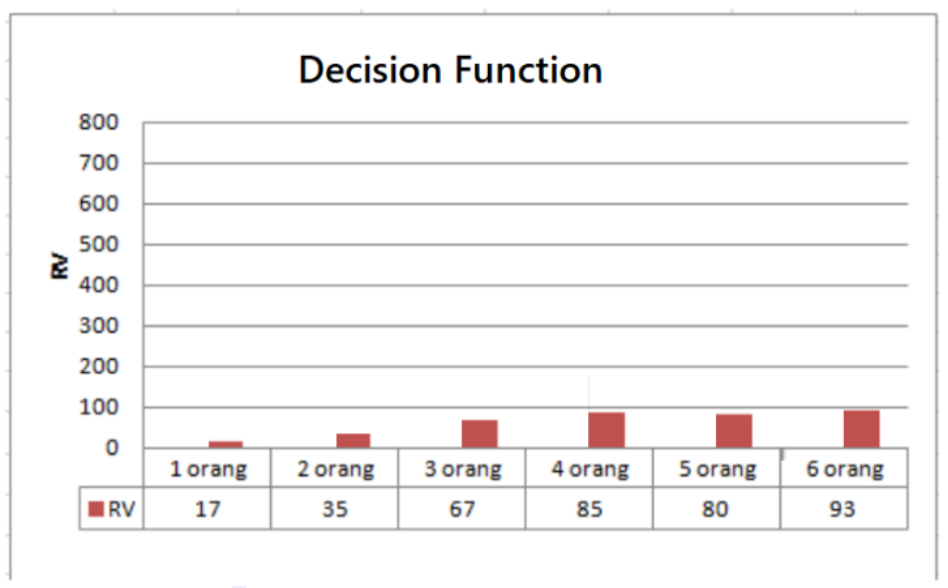

Gbr. 3 Jumlah Decision Function (Relevance Vector)

Untuk hasil training time dan testing time pada algoritma RVM diperlihatkan pada Tabel 1 . Algoritma RVM training membutuhkan waktu yang lebih banyak untuk menghitung prior information yang digunakan untuk memprediksi kelas sedangkan testing time, RVM membutuhkan waktu yang lebih sedikit karena RVM menghasilkan RV yang lebih sedikit.

TABEL I

HASIL TRAINING TIME DAN TESTING TIME ALGORITMA RVM

\begin{tabular}{ccc}
\hline \multirow{2}{*}{ Jumlah orang } & \multicolumn{2}{c}{ RVM } \\
\cline { 2 - 3 } & Training & Testing \\
\hline 1 orang & 3510 & 0.02 \\
2 orang & 9366 & 0.01 \\
3 orang & 53954 & 0.0001 \\
4 orang & 63671 & 0.15 \\
5 orang & 26258 & 0.02 \\
6 orang & 79160 & 0.15 \\
\hline
\end{tabular}

\section{Kesimpulan}

Penelitian dilakukan menggunakan data MRSC12 terdiri dari 12 gestures menggunakan algoritma RVM dengan kernel yang digunakan masingmasing taha-pan penelitian sama yaitu Radial Basis Function (RBF), dengan skala 0.3.

Setelah melakukan pemromesan data didapatkan hasil akurasi untuk 1 orang model gerak mencapai $100 \%$ dan akurasi terendah denngan 5 orang model gerak yang mencapai $96 \%$. Secara umum, semakin banyak jumlah orang atau model, maka semakin menurun akurasi algoritma.

\section{Referensi}

[1] V. Ayumi, "Pose-based human action recognition with Extreme Gradient Boosting," in Proceedings - 14th IEEE Student Conference on Research and Development: Advancing Technology for Humanity, SCOReD, 2017.

[2] C. Ma, J. Yang, G. Zenz, E. J. Staudacher, and L. Cheng, "Calibration of the microparameters of the discrete element method using a relevance vector machine and its application to rockfill materials," Adv. Eng. Softw., vol. 147, p. 102833, 2020. 
[3] S. K. Majumder, N. Ghosh, and P. K. Gupta, "Relevance vector machine for optical diagnosis of cancer," Lasers Surg. Med., vol. 36, no. 4, p. 4323333, 2005.

[4] D. F. Li, W. C. Hu, W. Xiong, and J. B. Yang, "Fuzzy relevance vector machine for learning from unbalanced data and noise," Pattern Recognit. Lett., vol. 29, no. 9, pp. 1175-1181, 2008.

[5] W. He, Y. Guo, and K. C. Yow, "Recognition of human activities using a multiclass relevance vector machine," Opt. Eng., vol. 51, no. 1, p. 017202, 2012.

[6] G. Pilikos, "The Relevance Vector Machine for Seismic Bayesian Compressive Sensing," Geophysics, vol. 85, no. 4, pp. 1-101, 2020.

[7] Y. Song, L. P. Morency, and R. Davis, "Distributionsensitive learning for imbalanced datasets," in 2013 10th IEEE International Conference and Workshops on Automatic Face and Gesture Recognition (FG), 2013, pp. $1-6$.

[8] J. Ding, M. Wang, Z. Ping, D. Fu, and V. S. Vassiliadis, "An Integrated Method Based on Relevance Vector Machine for Short-Term Load Forecasting," Eur. J. Oper. Res., 2020.

[9] E. Dong, K. Zhou, J. Tong, and S. Du, "A novel hybrid kernel function relevance vector machine for multi-task motor imagery EEG classification," Biomed. Signal Process. Control, vol. 60, p. 101991, 2020.

[10] D. Zou, L. Tong, J. Wang, S. Fan, and J. Ji, “A Logical
Framework of the Evidence Function Approximation Associated with Relevance Vector Machine," Math. Probl. Eng., 2020.

[11] D. Kong, Y. Chen, N. Li, C. Duan, L. Lu, and D. Chen, "Relevance vector machine for tool wear prediction," Mech. Syst. Signal Process., vol. 127, pp. 573-594, 2019.

[12] D. Ramayanti and U. Salamah, "Complaint Classification Using Support Vector Machine for Indonesian Text Dataset," Int. J. Sci. Res. Comput. Sci. Eng. Inf. Technol., vol. 3, no. 7, pp. 179-184, 2018.

[13] U. Salamah, "A Comparison of Text Classification Techniques Applied to Indonesian Text Dataset," Int. J. Sci. Res. Comput. Sci. Eng. Inf. Technol., vol. 5, no. 6, pp. 217-222, 2019.

[14] D. Ramayanti, "Comparison of Random Forest and Support Vector Machine for Indonesian Tweet Complaint Classification," Int. J. Sci. Res. Comput. Sci. Eng. Inf. Technol., vol. 5, no. 6, pp. 202-207, 2019.

[15] X. Chen and M. Koskela, "Skeleton-based action recognition with extreme learning machines," Neurocomputing, vol. 149, pp. 387-396, 2015. 